ISSN 1689-765X

\title{
Commodities as a Tool of Risk Diversification
}

JEL Classification: $G 02, G 11$

Keywords: commodities, diversification, portfolio

\begin{abstract}
Investing in commodities has become a new topic for private investors in recent years. Private investors are trying to spread their investments across a much wider spectrum of investments than in the past. They are looking for new sources of return and better diversification of investment risk. In this process, they are searching beyond the traditional asset classes of equities, bonds, cash and real estate. The objective of the paper is to critically explore the possibility of investing in commodities mainly for private investors and analyses investment characteristics. The main scientific aim is to use a complex of more sophisticated and theoretically advanced statistical techniques and apply them on the findings. This paper will provide comprehensive analyses of mostly used commodity indexes of 1 st generation and describe main differences between 1 st and 2 nd generation of commodity indexes and some examples of rollover mechanism will be critically explain. A representative of 2nd generation of commodity indexes was chosen for comprehensive data analysis to another asset class and for the testing whether commodities decreasing a risk of investment portfolio.
\end{abstract}

(C) Copyright Institute of Economic Research \& Polish Economic Society Branch in Torun Date of submission: February 9, 2013; date of acceptance: June 1, 2013

*Contact: skapa@fbm.vutbr.cz, Brno University of Technology, Faculty of Business and Management, Kolejní 2906/4, CZ-612 00 Brno, Czech Republic 


\section{Introduction}

Commodities are fundamentally different from stocks and bonds. While they are investable assets, they are not capital assets. Commodities do not generate a stream of dividends, interest payments, or other income that can be discounted in order to calculate a net present value. The Capital Asset Pricing Model does not apply to a bushel of corn. Rather, commodities are valued because they can be consumed or transformed into something else which can be consumed. However, there have been many routes investors have used to gain commodity exposure. The most common approach historically has been via owning the physical assets such as a gold bar. Another possibility is to use an index of products, as well as Exchange Traded Funds or Exchange Traded Commodities. One of the benefits of investing in commodities via an index is that an investor can gain exposure to a broad range of commodities, which tends to enhance diversification and reduce volatility. In addition, index investment can exploit the benefits of downward sloping forward curves, delivering a positive return. The aim of this paper is describe some representative commodity indexes, analyses them and make comparison to equities, bonds and cash and, secondly, make a mean-variance optimization of portfolios.

\section{Commodity Indices of $1^{\text {st }}$ and $2^{\text {nd }}$ Generation}

Commodity indices are an effective and efficient means for gaining access to the commodities. A commodity index is a grouping of commodity futures contracts that are rolled. Commodity indices provide returns comparable to passive long positions in listed futures contracts. Commodity indices attempt to replicate the returns available to holding long positions in agricultural, metal, energy, or livestock investment, without the investor having to actively manage the positions.

Historically, commodity indices can be constructed using several different methodologies, all of which will impact the returns and the underlying volatility of the index.

Commodities Research Bureau (CRB) Index: The CRB Index began trading on New York Futures Exchange in 1986 and is the oldest of the indices. While futures on the index began trading in 1986, it was first calculated by the CRB in 1957 and has data going back to 1958. The index included 17 individual components, which were equally weighted. In 2005 the index was renamed as Reuters/Jefferies CRB index (later as Thomson Reuters/Jefferies $\mathrm{CRB}$, after acquisition of Thomson by Reuters) and component weightings were changed to a four-tiered grouping system designed to more accurately 
reflect the significance of each commodity from 19 individual components (Reuters/Jefferies CRB).

Goldman Sachs Commodity Index (GSCI): The GSCI index was created in 1992 and is available in the form of a single futures contract on the Chicago Mercantile Exchange. While it was launched in 1992, the GSCI has backtested data going back to 1970 . The index consists of 24 individual components and weights are assigned based on a five-year moving average of world production values. The result is that the index has a heavier weighting in commodities with more economic importance and higher liquidity. Consequently, the GSCI has a weighting of nearly $70 \%$ in energy related commodities making its performance highly sensitive to the energy markets and fluctuations in energy prices. The GSCI is rebalanced annually, and utilizes an arithmetic average in constructing returns for the index. In 2008 the index was renamed as S\&P GSCI (S\&P Dow Jones Indices: S\&P GSCI ${ }^{\circledR}$ Methodology).

Dow Jones AIG (DJ-AIG) Index: The DJ-AIG was established in 1999 and relies primarily on liquidity data and, to a lesser extent, dollar-adjusted production data in determining the relative weights of commodities in the index. All data used in both the liquidity and production calculations are averaged over a five-year period to determine component weights. The index holds 20 components and limits any related group of commodities to $33 \%$ in order to ensure diversified exposure to commodities. Like the GSCI, the DJAIG index is rebalanced annually. The reason for using liquidity data rather than production data is that liquidity is an important indicator of the value placed on a commodity by financial and physical market participants. Production data alone can underestimate the investment value that financial market participants place on certain commodities. In 2009 the index was renamed as Dow Jones-UBS commodity Index (Dow Jones-UBS commodity Index Methodology).

Although there are many other commodities indexes today, these three have become the industry-standard benchmarks for commodities investing. Additionally, several other indices have gained popularity over the last few years, such as the Rogers International Commodity Index (RICI) and the Deutsche Bank Liquid Commodity Index (DBLCI). Table 1 summaries the key characteristics of these three indices. 
Table 1. Key characteristics of the commodity indices

\begin{tabular}{|c|c|c|c|}
\hline General characteristics & S\&P GSCI & DJ UBS CI & TRJ CRB \\
\hline Index inception & 1970 & 1991 & 1982 \\
\hline Investable since & 2001 & 1998 & 1986 \\
\hline $\begin{array}{l}\text { Number of commodities } \\
\text { included in the index }\end{array}$ & 24 & 19 & 19 \\
\hline Weighting methodology & $\begin{array}{l}\text { World production } \\
\text { weighted }\end{array}$ & $\begin{array}{l}2 / 3 \text { liquidity data } \\
\text { weighted and } 1 / 3 \\
\text { production } \\
\text { weighted }\end{array}$ & $\begin{array}{l}\text { Four-tiered group- } \\
\text { ing system }\end{array}$ \\
\hline $\begin{array}{l}\text { Rebalancing methodolo- } \\
\text { gy }\end{array}$ & Monthly & Annually & Monthly \\
\hline Roll frequency and dates & $\begin{array}{l}\text { Monthly, 5th- 9th } \\
\text { business day }\end{array}$ & $\begin{array}{l}\text { Monthly, 6th - } \\
\text { 10th business day }\end{array}$ & $\begin{array}{l}\text { Monthly, 1st }-4 \text { th } \\
\text { business day }\end{array}$ \\
\hline $\begin{array}{l}\text { Diversification con- } \\
\text { straints }\end{array}$ & None & $\begin{array}{l}33 \% \text { cap on sector, } \\
2 \% \text { minimum } \\
\text { weight }\end{array}$ & $\begin{array}{l}\text { Four-tiered group- } \\
\text { ing system }\end{array}$ \\
\hline Sector weights & - & - & - \\
\hline Energy & $70 \%$ & $33 \%$ & $39 \%$ \\
\hline $\begin{array}{l}\text { Metals (base and pre- } \\
\text { cious) }\end{array}$ & $11 \%$ & $26 \%$ & $20 \%$ \\
\hline Agriculture & $15 \%$ & $30 \%$ & $34 \%$ \\
\hline Livestock & $4 \%$ & $11 \%$ & $7 \%$ \\
\hline
\end{tabular}

Source: Dow Jones-UBS commodity Index Methodology Reuters/Jefferies CRB Methodology S\&P Dow Jones Indices: S\&P GSCI ${ }^{\circledR}$ Methodology.

All these indices are based on the concept of fully collateralised total returns. This means that there is no leverage implied in the strategy, as the full notional amount from the futures contracts is invested in a risk-free USD asset, usually in 3-month US T-bills. The index provider follows a rulebased strategy and automatically rolls the futures contracts before they expire. Most indices use near-term contracts with 0-3 months to expiration. By rolling these contracts on a regular basis, they can generate an additional source of return (or loss) as we will explain later on. As a basic concept, it is important for investors to understand that both interest income stemming from the collateral, as well as the ongoing rolling of the futures contracts, are significant performance drivers for commodity investments. Obviously, the actual price fluctuations of the underlying commodities are also important. 
These long-only commodity indices derive their returns from several sources, which are detailed below.

Collateral Yield: In a long-only commodity index, futures positions are unleveraged, meaning they must be fully collateralized, usually with Treasury Bills. Therefore, a portion of the return will come from the underlying cash position that supports the futures contract. Some managers seek to actively manage this underlying cash position in order to enhance the overall return of products tracking the index. Others simply invest the cash in shortterm Treasuries, which are then rolled over at maturity. Depending on the type of fixed income security used to collateralize positions in the long-only commodity index, the return on the underlying cash position could range from $0,1-4 \%$.

Rebalancing Yield: A second source of return from long-only commodity indices comes from what is known as the rebalancing yield. This portion of the return is attributable to the fact that commodity prices are not correlated with each another due to the varying factors that affect the price of each commodity. Because commodities do not rise and fall together, an index consisting of many commodities that is rebalanced regularly on a price basis is able to extract a return based on the tendency of commodities to revert to their mean prices. Historical data confirm that a price-rebalanced index will tend to extract a return from "buying low" and "selling high" the uncorrelated commodities. Robert Greer, senior vice president and portfolio manager for the PIMCO Real Return Fund, estimates that according to historical data, a commodities index can earn a rebalancing yield of approximately $2.5 \%$ on a long-term basis. The frequency of rebalancing is of particular importance, as data has shown that indices that rebalance more frequently are able to extract a greater return than those that rebalance less frequently.

Roll Yield: In addition to these two sources of return, a long-only commodity index will have gains associated with the change in price of the underlying commodities and the futures contracts on those commodities. For example, as a contract nears expiration, it will be "rolled over" to purchase new contracts on the commodity. At the time the position rolls over, there will be a gain or a loss depending on whether the underlying commodity has risen or declined in value. This portion of return is known as the "roll yield," and will depend in large part on whether the underlying commodities are increasing or decreasing in value as well as the allocations of various commodities in the index (Busken 2004).

These first generation of indexes have characteristics that may be of concern to investors. The indexes invest only in a single futures contract that is close to expiration. As a result, they must frequently roll their futures position forward to the next contract, leading to significant trading costs for index replication with exchange-traded futures. Also, from an investor per- 
spective, the front of the curve may not be the most desirable area to hold a long futures position. Indeed, in recent years, steep contango ${ }^{1}$ at the front end of many commodities futures curves has been blamed for degrading the returns of various commodities investment products, including those based on the S\&P GSCI and the DJ-UBSCI.

The problem of contango was solved by index provider and some strategies were found. The second generation of commodity indexes has become a reality. There are 2 representatives of second generation indexes:

The DJ-UBSCI 3 Month Forward Index (DJ-UBS CI F3) invests in the commodities contracts that the traditional DJ-UBSCI would hold three months from now. This feature places all the DJ-UBSCI F3 contracts farther out the futures curve, and since futures curves tend to be flatter as tenor is extended, the effects of backwardation and contango tend to be reduced (Dow Jones-UBS commodity Index Methodology, 2013). Comparing 15 years of back testing (1995-2010) there is difference of return approximately $1 \%$ p.a., the risk is nearly the same (Dynamic Roll of Commodities Futures: An Extended Framework, 2011). The same difference was fond in the period 2011-2012 when the UBSCI 3 Month Forward (DJ-UBS CI F3) exist in reality.

The Deutsche Bank Liquid Commodity Index - Optimum Yield Index has fixed weights for commodities, but for each commodity it selects the contract expiring within the next 13 months with the highest "implied roll yield". This enhancement can lessen the negative impact of contango and increase the positive effect of backwardation. Like the first-generation indexes, the DB Liquid Commodity Index - Optimum Yield continues to overweight the energy sector, which makes up 55 percent of the overall index (DBIQ Index Guide, 2006). Comparing 16 years of back testing plus 6 years "reality“ period, there is a difference of return nearly $3 \%$ p.a., the risk is nearly the same. (author's calculation according data the from DB).

All indexes are valuated in USD, and non-USD investor has to undergo currency risk. For Euro investors, Deutsche Bank introduced DBLCI-OY Balance Euro hedged index, which uses inherently Euro/USD hedging. DBLCI-OY Balance index holds 14 components and limits of any related group of commodities are set to $35 \%$ in order to ensure UCITS III Di-

\footnotetext{
${ }^{1}$ Contango - when longer-dated commodity prices are higher than shorter-dated commodity prices, the forward curve is said to be in "contango," that is, upward sloping. Markets in contango are generally characterized by low demand.

Backwardation is opposite to contando - when longer-dated commodity prices are lower than shorter-dated commodity prices, the forward curve is said to be in "backwardation," that is, downward sloping. Markets in backwardation are generally characterized by higher demand relative to available supply or limited supply relative to demand.
} 
rective $^{2}$. This commodity index has been covered by ETF since July 2007. And its composition is: 35\% Energy, 30\% Agriculture, 19\% Industry metals an $16 \%$ Precious metals (db x-trackers DBLCI - OY Balanced UCITS ETF (EUR), 2013).

\section{The Benefits of Commodities in a Portfolio}

Given the low correlation of commodities with traditional asset classes, like equities and fixed income, it has been observed that adding commodities to an investment portfolio improves the risk adjusted returns of the portfolio up to a certain point which varies based on the composition of the investment portfolio.

Traditional portfolio comprises $60 \%$ equities and $40 \%$ bonds. Two models of balanced portfolios with increasing portion of commodities are used. These two portfolios differ in stock part, for developed markets is used the MSCI World index in the first case, and the second one uses dividend strategy STOXX Global Select Dividend Index. Due to the better diversification of equity part two equity indexes were used, one covers developed markets and the other the emerging market - small capitalization firms.

Portfolio A

35 MSCI World NR

15 MSCI EM Small Cap NR

$40 \mathrm{iBx} €$ Eurozone 3-5y

10 EONIA

Portfolio B

35 STOXX 100 Global Select Dividend NR

15 MSCI EM Small Cap NR

40 iBx $€$ Eurozone 3-5y

10 EONIA

2 The Undertakings for Collective Investment in Transferable Securities, Directive (UCITS) are a set of European Union Directives that aim to allow collective investment schemes to operate freely throughout the EU on the basis of a single authorisation from one member state. In practice many EU member nations have imposed additional regulatory requirements that have impeded free operation with the effect of protecting local asset managers 
- Eonia is short for Euro Over Night Index Average. The Eonia rate is the 1-day interbank interest rate for the Euro zone. Eonia is taken as a proxy for cash deposit.

- MSCI World Net Return Index is the composite equity index covering countries in the developed markets. The index is capitalizations weighted.

- The MSCI Emerging Markets Small Cap Net Return Index is a capitalization-weighted performance index designed to provide a representation small capitalization emerging markets companies.

- STOXX Global Select Dividend 100 Net Return is the composite equity index covering countries in the developed markets. Companies are selected on the basis of dividend criteria and the weighting of the companies in the index is purely based on dividends.

- iBOXX $€$ SOVEREIGNS EUROZONE 3-5® represents the 3-5 years maturity Eurozone currency sovereign debt issued by Eurozone governments. The Index covers the Sovereigns Eurozone 3-5 years maturity bucket. Within the Index, each bond is weighted according to its amount outstanding. The Index is calculated and disseminated by Deutsche Börse and sponsored by International Index Company Limited ("IIC").

- DBLC Index ${ }^{\mathrm{TM}}$ - Optimum Yield Balanced is intended to reflect the performance of 14 commodities: WTI Crude Oil, Brent Crude Oil, Heating Oil, RBOB Gasoline, Natural Gas, Aluminium, Copper, Zinc, Gold, Silver, Wheat, Corn, Soybean and Sugar. Recomposition is done using the Optimum Yield methodology, which seeks to optimise the roll yield that will maximise the positive roll yield or minimise the negative roll yield. The index is currency hedged on a monthly basis. The index level is hedged by means of a forward contract with a maturity of one month. Index changes during the month are not hedged.

First, explanatory data analyses of all indices were made, the results being shown in Table 2. 56 quarterly data were obtained per each index. According the explanatory data analysis, one could say that medians are greater than means and trimmed means in all cases. In addition, kurtosis statistics show that the distributions have fatter tails than normally distributed variables. 
Table 2. Quarterly summary statistics of indices (data are expressed in Euro)

\begin{tabular}{|l|c|c|c|c|c|c|}
\cline { 2 - 7 } \multicolumn{1}{c|}{} & $\begin{array}{c}\text { DBLCI OY } \\
\text { EH }\end{array}$ & EONIA & $\begin{array}{c}\text { iBoxx } \\
\mathbf{3 - 5 y}\end{array}$ & $\begin{array}{c}\text { MSCI EM } \\
\text { SC }\end{array}$ & $\begin{array}{c}\text { MSCI } \\
\text { World }\end{array}$ & $\begin{array}{c}\text { STOXX Global } \\
\text { SD }\end{array}$ \\
\hline Count & 56 & 56 & 56 & 56 & 56 & 56 \\
\hline Average & 3,37 & 0,61 & 1,08 & 3,45 & 0,94 & 2,84 \\
\hline Median & 4,75 & 0,62 & 1,09 & 6,62 & 3,05 & 4 \\
\hline $\begin{array}{l}10 \% \\
\text { Trimmed } \\
\text { mean }\end{array}$ & 3,98 & 0,61 & 1,08 & 3,31 & 1,07 & 3,13 \\
\hline $\begin{array}{l}\text { Standard } \\
\text { deviation }\end{array}$ & 9,19 & 0,34 & 1,57 & 14,17 & 9,18 & 9,14 \\
\hline Minimum & $-30,7$ & 0,05 & $-2,54$ & $-25,3$ & $-20,7$ & $-28,8$ \\
\hline Maximum & 18,2 & 1,2 & 4,88 & 42,1 & 23,7 & 21,9 \\
\hline $\begin{array}{l}\text { Lower quar- } \\
\text { tile }\end{array}$ & $-1,55$ & 0,2 & $-0,07$ & $-7,75$ & $-4,25$ & $-1,85$ \\
\hline $\begin{array}{l}\text { Upper quar- } \\
\text { tile }\end{array}$ & 10,1 & 0,9 & 1,98 & 11,65 & 6,75 & 8,15 \\
\hline $\begin{array}{l}\text { Stnd. Skew- } \\
\text { ness }\end{array}$ & $-4,27$ & $-0,37$ & 0,06 & $-0,34$ & $-1,64$ & $-2,36$ \\
\hline $\begin{array}{l}\text { Stnd. Kurto- } \\
\text { sis }\end{array}$ & 4,92 & $-1,71$ & $-0,19$ & $-0,04$ & 0,68 & 2,91 \\
\hline
\end{tabular}

Source: Author's calculation.

Secondly, a Spearman rank of correlations between each pair of indexes was made which is shown in table 3. Sperman rank correlation is a bit robust than "traditional“ correlation (Pearson product-moment correlation coefficient). Sperman rank correlation coefficient is less sensitive to non-normality in distributions. According result of Spearman rank correlation is evident that the size of a correlation is small for commodities and equities and negative for commodities and bonds. 
Table 3. Spearman rank correlations

\begin{tabular}{|c|c|c|c|c|c|c|}
\hline & $\begin{array}{l}\text { DBLCI } \\
\text { OY EH }\end{array}$ & EONIA & $\begin{array}{c}\text { iBoxx } \\
3-5 y\end{array}$ & $\begin{array}{c}\text { MSCI } \\
\text { EM SC }\end{array}$ & $\begin{array}{l}\text { MSCI } \\
\text { World }\end{array}$ & $\begin{array}{c}\text { STOXX } \\
\text { Global SD }\end{array}$ \\
\hline \multirow{2}{*}{$\begin{array}{c}\text { DBLCI OY } \\
\text { EH }\end{array}$} & & $-0,07$ & $-0,33$ & 0,19 & 0,18 & 0,13 \\
\hline & & 0,57 & 0,02 & 0,15 & 0,17 & 0,34 \\
\hline \multirow{2}{*}{ EONIA } & $-0,07$ & & 0,12 & $-0,26$ & $-0,32$ & $-0,16$ \\
\hline & 0,57 & & 0,36 & 0,05 & 0,02 & 0,25 \\
\hline \multirow[t]{2}{*}{ iBoxx 3-5y } & $-0,32$ & 0,12 & & $-0,32$ & $-0,36$ & $-0,27$ \\
\hline & 0,02 & 0,36 & & 0,02 & 0,01 & 0,05 \\
\hline \multirow{2}{*}{$\begin{array}{l}\text { MSCI EM } \\
\text { SC }\end{array}$} & 0,19 & $-0,26$ & $-0,32$ & & 0,84 & 0,73 \\
\hline & 0,15 & 0,05 & 0,02 & & 0 & 0 \\
\hline \multirow[t]{2}{*}{ MSCI World } & 0,19 & $-0,32$ & $-0,36$ & 0,84 & & 0,82 \\
\hline & 0,17 & 0,02 & 0,01 & 0 & & 0 \\
\hline \multirow{2}{*}{$\begin{array}{c}\text { STOXX } \\
\text { Global SD }\end{array}$} & 0,13 & $-0,16$ & $-0,27$ & 0,73 & 0,82 & \\
\hline & 0,34 & 0,25 & 0,05 & 0 & 0 & \\
\hline
\end{tabular}

Source: Author's calculation.

Table 4 and Table 5 shows the portfolios based on the mean-variance optimization and its descriptive statistics for a traditional portfolio with stocks, bonds and small portion of cash as well as a portfolio with added commodities (increasing step is $10 \%$ part of commodities). These analyses suggest that it is attractive for an investor to add commodities. The Sharpe ratio increases from 0.242 to 0.533 for portfolio $A$, and from 0,531 to 0,692 for portfolio $B$.

Table 4. Summary statistics of portfolios A

\begin{tabular}{|l|c|c|c|c|c|}
\cline { 2 - 6 } \multicolumn{1}{c|}{} & Portf.A & Portf.A.10 & Portf.A.20 & Portf.A.30 & Portf.A.40 \\
\hline Count & 56 & 56 & 56 & 56 & 56 \\
\hline Average & 1,34 & 1,54 & 1,74 & 1,95 & 2,16 \\
\hline Median & 2,45 & 2,85 & 2,75 & 2,75 & 2,8 \\
\hline $\begin{array}{l}10 \% \\
\text { Trimmed } \\
\text { mean }\end{array}$ & 1,33 & 1,61 & 1,88 & 2,19 & 2,50 \\
\hline
\end{tabular}


Table 4 continued

\begin{tabular}{|l|c|c|c|c|c|}
\cline { 2 - 6 } \multicolumn{1}{c|}{} & Portf.A & Portf.A.10 & Portf.A.20 & Portf.A.30 & Portf.A.40 \\
\hline $\begin{array}{l}\text { Standard } \\
\text { deviation }\end{array}$ & 4,87 & 4,73 & 4,76 & 4,94 & 5,29 \\
\hline Minimum & $-9,4$ & $-10,9$ & $-13,1$ & $-15,4$ & $-17,5$ \\
\hline Maximum & 12,1 & 11,4 & 11,3 & 11,2 & 11,2 \\
\hline $\begin{array}{l}\text { Lower } \\
\text { quartile }\end{array}$ & $-1,9$ & $-1,3$ & $-1,2$ & $-0,85$ & $-0,6$ \\
\hline $\begin{array}{l}\text { Upper } \\
\text { quartile }\end{array}$ & 4,4 & 4,85 & 4,8 & 5,75 & 6,05 \\
\hline $\begin{array}{l}\text { Stnd. } \\
\text { Skewness }\end{array}$ & $-0,89$ & $-1,46$ & $-2,31$ & $-3,26$ & $-4,01$ \\
\hline $\begin{array}{l}\text { Stnd. kur- } \\
\text { tosis }\end{array}$ & $-0,22$ & 0,11 & 1,11 & 2,64 & 4,08 \\
\hline $\begin{array}{l}\text { Annualized } \\
\text { total return }\end{array}$ & 5,36 & 6,16 & 6,96 & 7,8 & 8,64 \\
\hline $\begin{array}{l}\text { Annualized } \\
\text { standard } \\
\text { deviation }\end{array}$ & 9,74 & 9,46 & 9,52 & 9,88 & 10,58 \\
\hline Sharpe(3\%) & 0,242 & 0,334 & 0,416 & 0,486 & 0,533 \\
\hline
\end{tabular}

Source: Author's calculation.

Table 5. Summary statistics of portfolios A

\begin{tabular}{|l|c|c|c|c|c|}
\cline { 2 - 6 } \multicolumn{1}{c|}{} & Portf.B & Portf.B.10 & Portf.B.20 & Portf.B.30 & Portf.B.40 \\
\hline Count & 56 & 56 & 56 & 56 & 56 \\
\hline Average & 2,02 & 2,14 & 2,28 & 2,42 & 2,56 \\
\hline Median & 3 & 3,35 & 3,25 & 3 & 3,2 \\
\hline $\begin{array}{l}10 \% \\
\text { Trimmed } \\
\text { mean }\end{array}$ & 2,07 & 2,22 & 2,43 & 2,67 & 2,91 \\
\hline $\begin{array}{l}\text { Standard } \\
\text { deviation }\end{array}$ & 4,78 & 4,62 & 4,65 & 4,86 & 5,23 \\
\hline Minimum & $-11,7$ & $-13,6$ & $-15,4$ & $-17,4$ & $-19,3$ \\
\hline Maximum & 14,4 & 14,1 & 13,7 & 13,3 & 12,9 \\
\hline $\begin{array}{l}\text { Lower } \\
\text { quartile }\end{array}$ & $-1,45$ & $-0,9$ & $-0,6$ & $-0,55$ & 0,15 \\
\hline $\begin{array}{l}\text { Upper } \\
\text { quartile }\end{array}$ & 4,75 & 5,05 & 5,4 & 5,6 & 6,3 \\
\hline
\end{tabular}


Table 5 continued

\begin{tabular}{|l|c|c|c|c|c|}
\cline { 2 - 6 } \multicolumn{1}{c|}{} & Portf.B & Portf.B.10 & Portf.B.20 & Portf.B.30 & Portf.B.40 \\
\hline $\begin{array}{l}\text { Stnd. } \\
\text { Skewness }\end{array}$ & $-1,05$ & $-1,73$ & $-2,79$ & $-3,92$ & $-4,76$ \\
\hline $\begin{array}{l}\text { Stnd. kur- } \\
\text { tosis }\end{array}$ & 1,29 & 2,53 & 4,52 & 6,41 & 7,52 \\
\hline $\begin{array}{l}\text { Annualized } \\
\text { total return }\end{array}$ & 8,08 & 8,56 & 9,12 & 9,68 & 10,24 \\
\hline $\begin{array}{l}\text { Annualized } \\
\text { standard } \\
\text { deviation }\end{array}$ & 9,56 & 9,24 & 9,3 & 9,72 & 10,46 \\
\hline Sharpe(3\%) & 0,531 & 0,602 & 0,658 & 0,687 & 0,692 \\
\hline
\end{tabular}

Source: Author's calculation.

The weight of the allocation to commodities covers the range from $10 \%$ to $40 \%$ for the demonstration and evaluation purpose of this paper $(40 \%$ weight is quite high allocation to commodities). It should be pointed out that the mean-variance optimization is sensitive to small changes and errors in the assumptions. Therefore, an acceptable maximum allocation should not exceed $25 \%$ (imperative of diversification).

\section{Conclusions}

Comprehensive analyses of mostly used commodity indexes of $1^{\text {st }}$ generation have been made in this paper. The main differences between $1^{\text {st }}$ and $2^{\text {nd }}$ generation of commodity indexes have been described, and some examples of rollover mechanism have been introduced and explained. A representative of $2^{\text {nd }}$ generation of commodity indexes was chosen for comprehensive data analyze to another asset class. For testing whether commodities decrease a risk of investment portfolio, two portfolios without commodity were made, and 8 portfolios with given weighting of commodities. The results have shown that direct commodity investment through commodity investable indexes can provide portfolio diversification benefits (improve return, or decrees risk or both). Adding a commodity component to a diversified portfolio of stocks, bonds and cash has been demonstrated to result in enhanced risk adjusted performance (Sharpe ratio). 


\section{References}

Busken, C. (2004), Investing in Commodities, http://www.feg.com/research.php.

DBIQ Index Guide - DBLCI Optimum Yield Commodity Indices https://index.db. $\mathrm{com} / \mathrm{htmlPages} /$ DBLCI-OY_v15.pdf (February 8th, 2013).

$d b \quad x$-trackers DBLCI - OY Balanced UCITS ETF (EUR), http://www.et f.db.com/DE/ pdf/DE/factsheet/factsheetLU0292106167_2013_01_31.pdf (February 14th, 2013).

Dynamic Roll of Commodities Futures: An Extended Framework, http://us.spindices. com/documents/research/DynamicRollofCommoditiesFuturesAnExtendedFrame workRebrand_Nov11_Final.pdf (February 11th, 2013).

Dow Jones-UBS commodity Index Methodology, http://www.djindexes.com/mdsidx/ downloads/meth_info/Dow_Jones_UBS_Commodity_Index_Methodology.pdf (February 8th, 2013).

Reuters/Jefferies CRB, http://www.jefferies.com/Commodities/2cc/389/ (summer 2005).

S\&P Dow Jones Indices: S\&P GSCI® Methodology, http://us.spindices.com/docum ents/methodologies/methodology-sp-gsci.pdf (February 8th, 2013). 